EXPERIMENTAL STUDY

\title{
Discerning malignancy in adrenocortical tumors: are molecular markers useful?
}

\author{
Christoph Wachenfeld, Felix Beuschlein ${ }^{1}$, Oliver Zwermann ${ }^{1}$, Patricia Mora ${ }^{1}$, Martin Fassnacht, Bruno Allolio \\ and Martin Reincke ${ }^{1}$ \\ Schwerpunkt Endokrinologie, Medizinische Universitätsklinik Würzburg, Würzburg, Germany and ${ }^{1}$ Schwerpunkt Endokrinologie, \\ Abteilung Innere Medizin II, Klinikum der Universität Freiburg, Freiburg, Germany \\ (Correspondence should be addressed to M Reincke, Division of Endocrinology, Medical Department II, Klinikum der Albert-Ludwigs-Universität Freiburg, \\ Hugstetterstr. 55, 97106 Freiburg, Germany; Email: reincke@med1.ukl.uni-freiburg.de)
}

\begin{abstract}
Objective: Adrenocortical carcinoma (ACC) is a rare neoplasm with poor prognosis. Discerning ACCs from benign adenomas histologically may be difficult if invasion into surrounding tissues or metastases are missing.

Design: In order to establish molecular markers for malignancy, we analyzed seven normal adrenals, three massive macronodular ACTH-independent adrenocortical hyperplasias (MMAHs), 30 adrenocortical adenomas (ACAs) and ten ACCs.

Methods: All tissues were studied for the presence of alterations in the p53 tumor suppressor gene using the PAb 1801 antibody, which detects mutant p53 protein and the pYNZ22 microsatellite marker to show loss of heterozygosity $(\mathrm{LOH})$ at $17 \mathrm{p}$, for expression of the proliferation-associated antigen Ki67 using the MIB1 antibody, for the rate of apoptotic tumor cells with the TdT-mediated dUTP biotin nick end labeling (TUNEL) method, and for LOH of 11q13 (menin gene locus) with the D11S956 microsatellite marker.

Results: 0/3 MMAH, 1/28 ACA and 3/10 ACC revealed immunopositive staining for p53. LOH for pYNZ22 was observed in 1/3 MMAH, 1/23 informative ACA and 6/6 informative ACC. The rate of apoptotic cells was significantly higher in ACC $(P<0.0001$ by ANOVA) than in ACA but there was some overlap between groups. The Ki67 index (\% immunopositive cells) was $1.9 \pm 1.30 \%$ (mean \pm S.D.) in normal adrenals, $3.47 \pm 1.37 \%$ in MMAH, and $2.11 \pm 1.01 \%$ in ACA. ACC had the highest Ki67 index of $11.94 \pm 7.58 \%$ distinguishing all ACC from the ACA and MMAH studied with a cut-off level of 5\%. LOH for 11q13 was detected in 2/3 MMAH, 5/26 ACA and 6/8 ACC.

Conclusions: We conclude that a Ki67 index above 5\% is a sensitive and specific indicator of ACC and may be useful in the differentiation of adenomas from carcinomas.

European Journal of Endocrinology 145 335-341
\end{abstract}

\section{Introduction}

Between 1.4 and $8.7 \%$ of all autopsies and roughly $1 \%$ of all abdominal CT scans reveal clinically nonrecognized adrenal tumors. The majority of these incidentally discovered adrenal masses has little or no impact on the patient's health. Although adrenocortical carcinoma (ACC) is rare - the incidence is approximately 1 per 1.7 million inhabitants per year in the USA - its highly aggressive behavior and 2 years survival rate of only $50 \%$ makes exclusion of malignancy desirable in all adrenal tumors $(1,2)$. Assessing the malignant potential of adrenal tumors in vivo with non-invasive diagnostic techniques is difficult. Tumor size, endocrine activity and differences of signal intensity in $T_{1}$ and $T_{2}$-weighted magnetic resonance imaging scans are helpful (3). Because of the high number of benign clinically silent adrenal adenomas, surgical removal is only recommended in larger tumors, since in small tumors the benefits do not outweigh the risks of surgery $(4,5)$.

Discerning malignancy in adrenal tumors is often difficult even in resected tumors. In adrenocortical tumors, Hough et al., Weiss et al. and van Slooten et al. established algorithms of histopathological features to diagnose malignancy (6-9). However, these algorithms are of limited value under routine conditions, especially since some of the criteria require clinical information, which may not be available in every case. Reliable molecular or immunohistochemical markers hold the potential to make assessment of adrenal malignancy much easier, as it has been shown for other endocrine and non-endocrine tumors. For example, loss of expression of the retinoblastoma gene product has 
been proven to be useful in the diagnosis of parathyroid carcinoma $(10,11)$ unless some overlap between benign and malignant lesion has to be considered (12). Several groups have tried to establish markers for malignancy in adrenocortical tumors. Overexpression of insulin-like growth factor-II (IGF-II, ref. 13), IGF-I receptor (14) and high levels of IGF-binding protein-2 (15) have been demonstrated in a high percentage of malignant adrenocortical tumors, but has not been detected in benign adrenal tumors. Marx et al. (16) found that abrogation of MHC class II expression was a feature of ACC but may be found in some adenomas as well. After investigating cellular DNA content by flow cytometry and immunohistochemical distribution of c-myc, vimentin, proliferating cell nuclear antigen (PCNA) and epidermal growth factor receptor, Suzuki et al. concluded that only DNA ploidy and distribution of immunohistologically detectable c-myc oncoprotein has some diagnostic value and that morphologic and clinical studies are the best available methods in discerning malignancy in adrenocortical neoplasms (17). Cote et al. (18) found expression of low-molecular weight cytokeratin intermediate filaments in ACA (adrenocortical adenoma) and normal adrenal but not in seven ACCs. In contrast, vimentin was seen in all ACCs studied and was heterogeneously expressed by ACAs. They conclude that undetectable expression of cytokeratins and strong expression of vimentin is associated with malignant adrenal cortical lesions (18). Goldblum et al. showed that PCNA expression does not correlate with histological diagnosis and clinical outcome in adrenal tumors, however, Ki67 expression significantly does (19).

In order to test the diagnostic potential of molecular markers in adrenocortical neoplasms we studied 43 adrenocortical masses, evaluating the use of p53 tumor suppressor gene alterations (20, 21), Ki67 expression, the rate of apoptosis, and allelic loss at the 11q13 locus near the multiple endocrine neoplasia type-1 (MEN-1) gene $(22,23)$ in differentiating benign from malignant lesions.

\section{Patients and methods}

\section{Patients and DNA isolation}

We studied 43 patients with a variety of adrenal diseases (clinical data see Table 1). Neoplastic tissue was obtained at adrenalectomy. The tissue was snapfrozen immediately and stored at $-80{ }^{\circ} \mathrm{C}$ for a maximum of 11 years. Diagnosis was made by clinical and histological data following established criteria $(8$, 9 ), together with a follow-up of the patients for a minimum of 12 month (24). Endocrine work up included measurement of urinary free cortisol, serum renin and aldosterone, urinary tetrahydroaldosterone, urinary catecholamine and performing of low dose dexamethasone suppression test where applicable. Blood was simultaneously collected for leukocyte DNA extraction. DNA was isolated from frozen tissue and leukocytes using the Qiagen Blood \& Cell Culture DNA Kit and protocol (Qiagen, Hilden, Germany). Seven human adrenal glands were obtained from brain-dead patients during organ removal for transplantation and studied as reference tissue.

\section{p53 Immunohistochemistry and loss of heterozygosity of $17 p$}

Immunohistochemistry was performed on frozen tumor sections using the monoclonal IgG mouse antibody PAb 1801 (Ab 2, Oncogene Science, Manhassed, NY, USA) according to the instructions of the manufacturer and described in detail previously (20). Loss of heterozygosity (LOH) indicating allelic loss was analyzed with the pYNZ22 microsatellite, a variable number of tandem repeat (VNTR) marker at $17 \mathrm{p}$ near the p53 gene. The rate of heterozygosity in examined populations is approximately $80 \%$ (25). DNA from frozen tissue or leukocyte DNA was amplified by PCR and analyzed by ethidium bromide stained agarose gel electrophoresis. Primers, protocol and PCR conditions were similar to those reported recently (20). Data of p53 immunohistochemistry from 25 out of the 50 samples of the present series have been published previously (20).

\section{TdT-mediated dUTP biotin 3'OH nick end labeling (TUNEL)}

The rate of apoptotic cells was assessed by the TUNEL method (26). In brief, $10 \mu \mathrm{m}$ tissue cryosections were fixed and incubated with the TdT enzyme at $37{ }^{\circ} \mathrm{C}$ as primary antibody; a peroxidase coupled digoxigenin antibody was used as secondary antibody and

Table 1 Clinical data of the patients studied.

\begin{tabular}{lcccc}
\hline Diagnosis & $\boldsymbol{n}$ & $\begin{array}{c}\text { Mean age in } \\
\text { years (range) }\end{array}$ & $\begin{array}{c}\text { Mean tumor } \\
\text { size }(\mathrm{cm})\end{array}$ & $\begin{array}{c}\text { Range of tumor } \\
\text { size }(\mathrm{cm})\end{array}$ \\
$\begin{array}{l}\text { Human adrenal glands* } \\
\text { MMAH }\end{array}$ & 7 & $42(15-68)$ & - & - \\
$\mathbf{( F / M )}$
\end{tabular}

*Human adrenal glands were obtained from brain-dead patients during organ removal for transplantation. $\mathrm{F}$, female; M, male. 
Table 2 p53 alterations, apoptosis, Ki67 index and LOH of 11q13 in sporadic adrenal tumors. The number of non-informative cases is shown in parentheses. $P$ value for significance of difference: Carcinoma vs adenoma ${ }^{*} P<0.0001$.

\begin{tabular}{|c|c|c|c|c|c|c|}
\hline \multirow[b]{2}{*}{ Diagnosis } & \multirow[b]{2}{*}{$n$} & \multicolumn{2}{|c|}{ p53 alterations } & \multirow[b]{2}{*}{$\begin{array}{l}\text { Apoptosis: } \\
\% \text { TUNEL-positive } \\
\text { cells } \pm \text { s.D. }\end{array}$} & \multirow[b]{2}{*}{$\begin{array}{c}\text { Proliferation: } \\
\% \text { Ki67-positive } \\
\text { cells } \pm \text { s.D. }\end{array}$} & \multirow[b]{2}{*}{$\begin{array}{c}\text { MEN-1 locus } \\
\text { LOH at D11S956 }\end{array}$} \\
\hline & & $\begin{array}{c}\text { p53 } \\
\text { over- } \\
\text { expression }\end{array}$ & $\begin{array}{l}\text { LOH at } \\
\text { pYNZ22 }\end{array}$ & & & \\
\hline Human adrenal glands & 7 & - & - & $0.19 \pm 0.06$ & $1.89 \pm 1.30$ & - \\
\hline MMAH & 3 & $0 / 3(0)$ & $1 / 3(0)$ & $0.50 \pm 0.31$ & $3.47 \pm 1.37$ & $2^{a} / 3(0)$ \\
\hline Adrenal adenoma & 30 & $1 / 28(2)$ & $1 / 23(7)$ & $0.44 \pm 0.29$ & $2.11 \pm 1.01$ & $5 / 26(4)$ \\
\hline Adrenal carcinoma & 10 & $3 / 10(0)$ & $5 / 5(2)$ & $4.57 \pm 4.43^{*}$ & $11.94 \pm 7.58^{*}$ & $6 / 8(2)$ \\
\hline
\end{tabular}

${ }^{\mathrm{a}} \mathrm{LOH}$ was present in some but not all noduli.

positive cells were visualized with diaminobenzidine as chromogen. Specimens were counterstained with methyl green. All reagents and protocols were supplied by the manufacturer (Oncor, Gaithersburg, MD, USA).

\section{Ki67 Immunohistochemistry}

On $10 \mu \mathrm{m}$ tissue cryosections, pretreated with blocking serum, the monoclonal antibody MIB1 (Dianova, Hamburg, Germany) was used to detect specifically Ki67 antigen. Bound MIB1 antibody was conjugated with a biotinylated IgG. Ki67 positive cells were finally visualized by the biotin-avidin-peroxidase complex system revealing a brown nuclear signal. Specimens were counterstained with hematoxylin.

\section{Analysis of immunohistological data}

At a magnification of $500 \times$ the number of positive cells were counted and divided by the number of total cells per high power field (HPF). For each tumor the mean of five HPFs was calculated and expressed as percentage (\%) positive cells. p53 overexpression was defined as nuclear p53 immunoreactivity in more than $1 \%$ of tumor cells.

\section{$11 q 13$ LOH}

D11S956 is a VNTR marker on 11q13 at the centromeric side of the MEN-1 gene locus. Its rate of heterozygosity is $88 \%$ (27). PCR was used to amplify the alleles according to the following protocol: initial denaturation at $94{ }^{\circ} \mathrm{C}$ for $3 \mathrm{~min}$, followed by 27 cycles (denaturation at $94{ }^{\circ} \mathrm{C}$ for $1 \mathrm{~min}$, annealing at $55^{\circ} \mathrm{C}$ for $2 \mathrm{~min}$ and primer extension at $72{ }^{\circ} \mathrm{C}$ for $1 \mathrm{~min}$ ), terminated by a final step of primer extension at $72{ }^{\circ} \mathrm{C}$ for $6 \mathrm{~min}$. The primers used were: $5^{\prime}$-GATCAGTAATTAGCCAGACTCTAGG-3' and 5'-GGTTTTGGAGCTTAAGGAGG-3' (27).

\section{Statistics}

All values are expressed as mean \pm S.D. Significance of differences was assessed by ANOVA using the StatView
5.0 (SAS Institute, Cary, NC, USA). A $P<0.05$ was considered statistically significant. Correlation between parameters was determined by linear regression analysis.

\section{Results}

\section{p53 alterations}

Overexpression of p53 was detected in none of massive macronodular ACTH-independent adrenocortical hyperplasias (MMAH), was rarely present in ACA (1/ 28 ), but was found in approximately $30 \%$ of ACC (Table 2). LOH of p53 was rarely found in benign lesions $(1 / 23)$, but in all ACC informative for pYNZ22 $(n=6)$.

\section{Apoptosis}

The rate of apoptotic cells was significantly higher $(P<0.0001)$ in ACC than in the other adrenocortical tissues (Fig. 1), but there was some overlap between groups, limiting its prognostic significance. Two out of

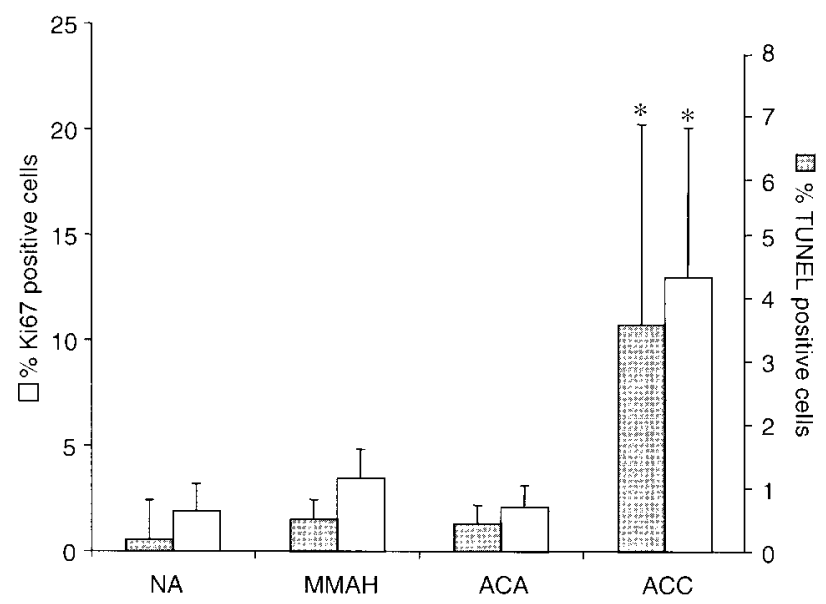

Figure 1 Mean ( \pm S.D.) rate of apoptotic cells (gray bars) and Ki67positive cells (white bars) of the different tissues. ${ }^{*} P<0.0001$, $A C C$ vs $A C A$. NA=normal adrenal. 


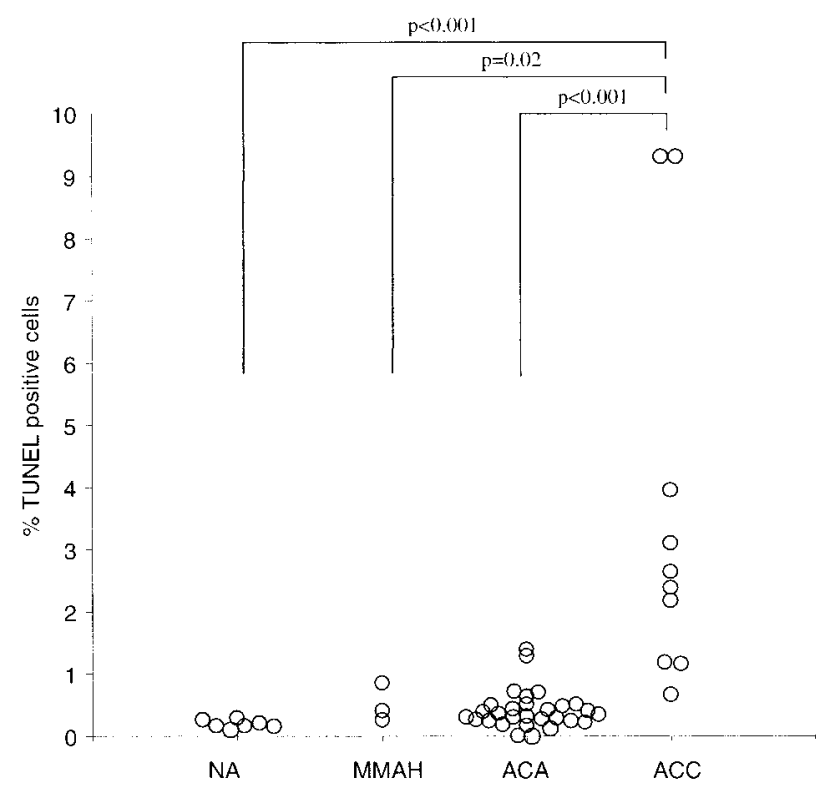

Figure 2 Apoptosis index: distribution in normal adrenal (NA), MMAH, ACA and ACC.

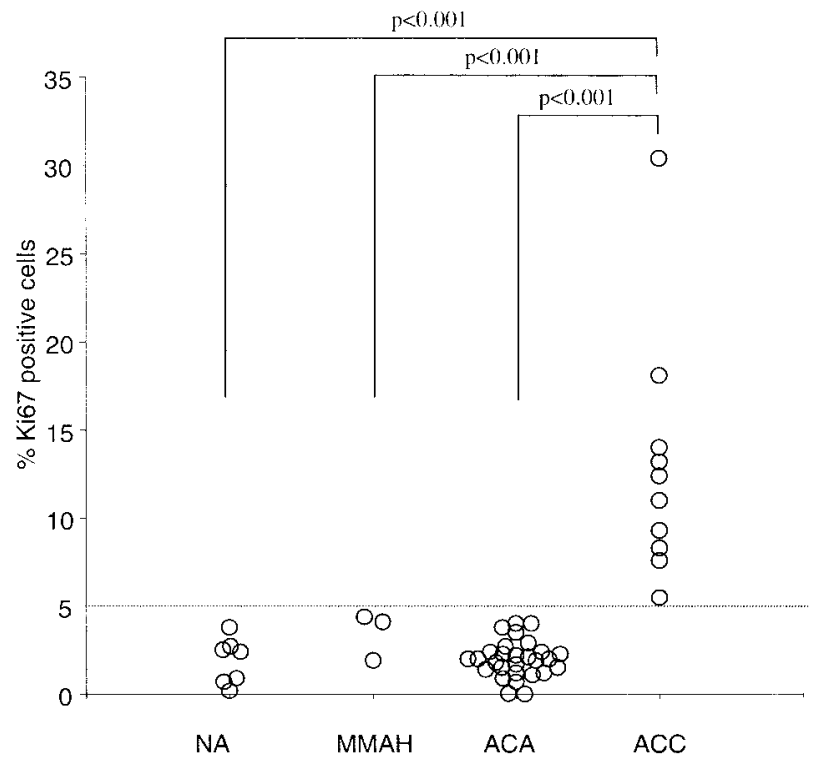

Figure 3 Ki67 index: distribution in normal adrenal (NA), MMAH, ACA and ACC. The line represents the cut-off between ACA and ACC of $5 \%$.
$30(6.6 \%)$ ACA had an apoptotic index higher than 1\% and 1/10 (10.0\%) ACC had one lower than 1\% (Fig. 2).

\section{Ki67 expression}

ACC had the highest Ki67 index $(12.98 \pm 7.11 \%)$ of all adrenocortical tumors (human adrenal glands $1.9 \pm$ $1.30 \%$, MMAH $3.47 \pm 1.37 \%$, ACA $2.11 \pm 1.01 \%$ ) distinguishing significantly $(P<0.0001$; Fig. 1) all carcinomas from benign adrenocortical tumors without any overlap (cut-off level 5\%, Fig. 3). A weak but significant correlation between Ki67 expression and apoptotic index could be detected in the tissues studied $\left(R^{2}=0.15, P=0.04\right)$.

\section{LOH at the MEN-1 locus}

LOH of $11 \mathrm{q} 13$ was found in $19 \%(5 / 26)$ of ACA and $75 \%(6 / 8)$ of ACC. None of the ACA revealed LOH of the MEN-1 locus and of the p53 gene locus whereas six of ten ACC proved to have $\mathrm{LOH}$ of both loci (Table 3) (Fig. 4).

\section{Discussion}

The main finding of our study is that a Ki67 staining index over $5 \%$ separates benign from malignant adrenocortical tumors without overlap (Fig. 3). This indicates that a Ki67 index greater than $5 \%$ is a good marker for malignancy in adrenocortical neoplasms. Our data extend the recent findings of Goldblum et al. (18). Using archival material they showed that the Ki67 index was higher in 15 ACC compared with 19 ACA. However, in their series, 6 of 15 carcinomas had a Ki67 labeling index within the range of adenomas, limiting its diagnostic significance as a marker for malignancy. The discrepancy with our series may be due to technical differences. Whereas fresh frozen tumor tissue in the present series gave an intense nuclear Ki67 signal, Ki67 staining as reported by Goldblum et al. was shown to be discrete and sometimes cytoplasmic in localization. This is probably due to formalin fixation of the tissue with decreased protein antigenicity and/or reduced nuclear penetration of the antibody resulting in underestimation of the true number of Ki67-positive cells.

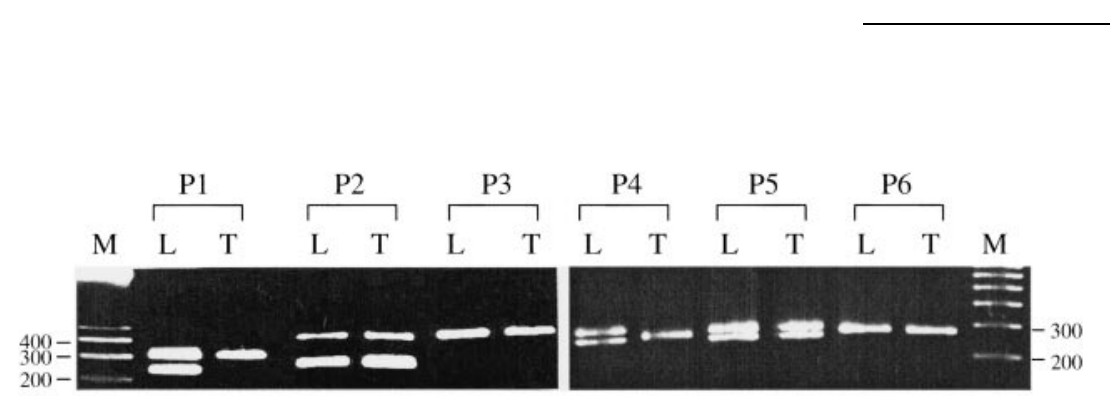

Figure $4 \mathrm{LOH}$ studies: $\mathrm{LOH}$ indicating allelic loss was analyzed with the pYNZ22 microsatellite marker near the p53 gene (patients 1-3) and D11S956 marker on $11 \mathrm{q} 13$ at the centromeric side of the MEN-1 gene locus (patients 4-6). $\mathrm{LOH}$ of tumor DNA in patients 1 (ACC) and 4 (ACA), no $\mathrm{LOH}$ of tumor DNA in patients 2 (ACA) and 5 (ACC), non-informative patient 3 (pheochromocytoma) and 6 (adrenocortical adenoma). $M=$ marker, $L=$ leucocyte DNA, T=tumor DNA. 
Table 3 Results for 43 adrenal leasions and seven human adrenal glands investigated for p53 alterations, apoptosis, proliferation and $\mathrm{LOH}$ of $11 \mathrm{q} 13$. $\mathrm{NA}=$ normal adrenal.

\begin{tabular}{|c|c|c|c|c|c|c|}
\hline \multirow[b]{2}{*}{ No. } & \multirow[b]{2}{*}{ Diagnosis } & \multicolumn{2}{|c|}{ p53 alterations } & \multirow[b]{2}{*}{$\begin{array}{l}\text { Apoptosis: } \\
\% \text { TUNEL-positive cell }\end{array}$} & \multirow[b]{2}{*}{$\begin{array}{c}\text { Proliferation: } \\
\% \text { Ki67-positive cells }\end{array}$} & \multirow[b]{2}{*}{$\begin{array}{c}\text { MEN-1 locus } \\
\text { LOH at D11S956 }\end{array}$} \\
\hline & & $\begin{array}{c}\text { p53 } \\
\text { over-expression }\end{array}$ & $\begin{array}{l}\mathrm{LOH} \text { at } \\
\text { pYNZ22 }\end{array}$ & & & \\
\hline 1 & NA & I & I & 0.10 & 0.90 & I \\
\hline 2 & NA & I & I & 0.16 & 3.80 & I \\
\hline 3 & NA & I & I & 0.28 & 2.50 & I \\
\hline 4 & NA & I & I & 0.16 & 2.40 & I \\
\hline 5 & NA & I & I & 0.15 & 0.70 & I \\
\hline 6 & NA & I & I & 0.20 & 2.70 & I \\
\hline 7 & NA & I & I & 0.25 & 0.20 & I \\
\hline 8 & MMAH & - & + & 0.85 & 4.10 & + \\
\hline 9 & MMAH & - & - & 0.25 & 4.40 & - \\
\hline 10 & MMAH & - & - & 0.4 & 1.9 & $t^{a}$ \\
\hline 11 & ACA & - & - & n.i. & 0.03 & - \\
\hline 12 & ACA & - & - & 0.31 & 2.70 & - \\
\hline 13 & ACA & - & - & 0.26 & 0.00 & + \\
\hline 14 & $\mathrm{ACA}$ & - & - & n.i. & 4.00 & + \\
\hline 15 & ACA & n.i & n.i. & 0.43 & 2.20 & + \\
\hline 16 & ACA & - & - & 0.31 & 1.70 & n.i. \\
\hline 17 & ACA & - & - & 0.40 & 1.50 & + \\
\hline 18 & ACA & - & - & 0.42 & 0.90 & - \\
\hline 19 & ACA & - & n.i. & 0.34 & 1.20 & - \\
\hline 20 & ACA & - & n.i. & 0.22 & 1.10 & - \\
\hline 21 & $\mathrm{ACA}$ & - & - & 0.17 & 1.40 & - \\
\hline 22 & ACA & - & - & 0.18 & 1.50 & - \\
\hline 23 & ACA & - & - & 0.24 & 4.00 & - \\
\hline 24 & $A C A$ & - & - & 0.51 & 2.10 & - \\
\hline 25 & ACA & - & - & 0.24 & 2.90 & - \\
\hline 26 & $\mathrm{ACA}$ & - & - & 0.30 & 3.50 & - \\
\hline 27 & ACA & n.i. & - & 0.39 & 2.00 & n.i. \\
\hline 28 & ACA & - & - & 0.28 & 3.80 & - \\
\hline 29 & ACA & - & n.i. & 0.36 & 0.70 & - \\
\hline 30 & $A C A$ & - & n.i. & 0.27 & 2.00 & - \\
\hline 31 & $A C A$ & - & - & 0.63 & 1.20 & n.i \\
\hline 32 & ACA & - & n.i. & 0.49 & 2.00 & - \\
\hline 33 & $\mathrm{ACA}$ & - & - & 0.51 & 3.50 & - \\
\hline 34 & ACA & - & n.i. & 0.30 & 2.40 & - \\
\hline 35 & ACA & - & - & 0.12 & 4.00 & - \\
\hline 36 & $A C A$ & - & - & 0.71 & 1.90 & + \\
\hline 37 & ACA & - & - & 0.48 & 2.30 & - \\
\hline 38 & ACA & - & - & 1.28 & 2.30 & - \\
\hline 39 & ACA & + & + & 0.70 & 1.80 & n.i. \\
\hline 40 & ACA & - & - & 1.39 & 2.40 & - \\
\hline 41 & ACC & - & n.i. & 3.95 & 7.60 & - \\
\hline 42 & ACC & - & + & 1.16 & 9.30 & + \\
\hline 43 & ACC & + & n.i. & 1.18 & 13.20 & - \\
\hline 44 & ACC & + & + & 2.64 & 8.30 & + \\
\hline 45 & ACC & - & + & 0.66 & 14.00 & + \\
\hline 46 & ACC & - & + & 2.38 & 18.10 & + \\
\hline 47 & ACC & + & + & 2.17 & 30.40 & + \\
\hline 48 & ACC & - & & 3.1 & 11.0 & n.i. \\
\hline 49 & ACC & - & & 9.3 & 5.5 & + \\
\hline 50 & ACC & - & & 9.3 & 12.4 & n.i. \\
\hline
\end{tabular}

aOH in one of two noduli analysed. n.i. = non-informative, $/=$ not performed.

Data on the importance of the cell proliferation indices like Ki67 have been collected in other endocrine and non-endocrine tissues tumors. Vargas and colleagues found that more than 4\% MIB1-positive cells in parathyroid tumors correlated strongly with malignancy (28). In pituitary adenomas, a Ki67 index higher than $1 \%$ predisposed to rapid tumor growth 2 years after initial surgery (29). To identify variables potentially predictive of malignancy among nonfunctioning pancreatic endocrine tumors, La-Rosa et al. found that vascular or perineural microinvasion and Ki67 proliferative index $>2 \%$ were the most sensitive and specific variables correlated with malignancy (30). Basolo and colleagues (31) investigated 92 
thyroid carcinomas of different histotypes for apoptotic and Ki67 indices. Whereas the apoptotic index was low in all subtypes of thyroid carcinoma, the Ki67 index was significantly different among the histotypes, increasing with tumor aggressiveness from 3.1\% for papillary carcinoma to $5.6 \%$ for poorly differentiated carcinoma and $51.8 \%$ for undifferentiated carcinoma (31). Garzetti et al. reported that in comparison to cystoadenomas and borderline tumors, the Ki67 antigen immunostaining was significantly higher in ovarian cystoadenocarcinomas. Additionally, a significant relationship was observed between the Ki67 index and disease-free survival (32). Albers et al. reported in patients with clinical stage A non-seminomatous germ cell tumors who consecutively underwent retroperitoneal lymph node dissection that only those cases revealed metastases that had a MIB1 value higher than $52 \%(33)$.

In our series, p53 tumor suppressor gene alterations and $\mathrm{LOH}$ of 11q13 alone were not very useful markers. $\mathrm{LOH}$ of $17 \mathrm{p}$ and an elevated apoptotic index was predominantly seen in ACC. Those findings may provide a clue to malignancy in a given tumor, but also occur in ACA, limiting its prognostic significance. According to our series, combinations of these markers can give additional information if the malignant potential of a tumor is unknown: $\mathrm{LOH}$ of both $17 \mathrm{p}$ and 11q13 was present in none of the ACA, compared with 6/10 ACC. On the other hand, absence of p53 alterations and $\mathrm{LOH}$ of $11 \mathrm{q} 13$ together with a low apoptotic index makes malignancy unlikely in a given tumor (Table 3 and Fig. 2).

Our findings may have an impact on the approach to patients with incidentally detected adrenal masses. There is general agreement that adrenal tumors larger than 4-5 $\mathrm{cm}$ should be removed because of the risk of malignancy $(4,34)$. In these patients, careful analysis of the tumor tissue is required to identify those patients who harbor an ACC. In the past, identification of well differentiated ACC among benign ACA by means of histopathology was time-consuming and required specialist knowledge, as outlined recently $(6,8)$. Determination of Ki67 content, possibly in combination with other markers, could help to determine the malignant potential of a given tumor with more accuracy.

Surgical removal is not generally recommended in adrenal incidentalomas smaller than $5 \mathrm{~cm}$ in diameter. A frequently used method to evaluate a tumor's malignant potential in these cases is CT or ultrasound-guided fine needle aspiration biopsy or cutting biopsy. However, this approach is controversial, since the small amount of tissue yielded by the procedure makes the assessment of the pathological criteria (invasion of venous and sinusoidals, necrosis, fibrous bands, tumor architecture, etc.) almost impossible. Adrenal biopsies are also associated with considerable morbidity and mortality due to pneumothorax, hemorrhage, incidental puncture of pheochromocytomas and needle tract metastases outweighing the benefits for the patient. In this setting, reliable markers for malignancy could be a strong argument for biopsy, especially in the evaluation of small but suspicious silent adrenal masses.

In conclusion, in our series a Ki67 index above 5\% was a valuable marker for malignancy in adrenocortical neoplasms. A high apoptotic index, especially in combination with $\mathrm{LOH}$ of $17 \mathrm{p}$ and $11 \mathrm{q} 13$, raises the probability of ACC.

\section{Acknowledgements}

Supported by Dr Mildred-Scheel-Stiftung.

\section{References}

1 Copeland PM. The incidentally discovered adrenal mass. Annals of Internal Medicine 198398 940-945.

2 Lipsett MB, Hertz R \& Ross GT. Clinical and pathophysiologic aspects of adrenocortical carcinoma. American Journal of Medicine $196335374-383$.

3 Krestin GP, Steinbrich W \& Friedmann G. Adrenal masses: evaluation with fast gradient-echo MR imaging and Gd-DTPAenhanced dynamic studies. Radiology 1989171 675-680.

4 Mantero F, Terzolo M, Arnaldi G, Osella G, Masini AM, Ali A et al. A survey on adrenal incidentaloma in Italy. Study Group on Adrenal Tumors of the Italian Society of Endocrinology. Journal of Clinical Endocrinology and Metabolism 200085 637-644.

5 Siren J, Tervahartiala P, Sivula A \& Haapiainen R. Natural course of adrenal incidentalomas: seven-year follow-up study. World Journal of Surgery 200024 579-582.

6 Hough AJ, Hollifield JW, Page DL \& Hartmann WH. Prognostic factors in adrenal cortical tumors: a mathematical analysis of clinical and morphologic data. American Journal of Clinical Pathology 197972 390-399.

7 Weiss LM. Comparative histologic study of 43 metastasizing and nonmetastasizing adrenocortical tumors. American Journal of Surgical Pathology 19848 163-169.

8 Weiss LM, Medeiros LJ \& Vickery AL. Pathologic features of prognostic significance in adrenocortical carcinoma. American Journal of Surgical Pathology 198913 202-206.

9 Van Slooten H, Schaberg A, Smeenk D \& Moolenaar AJ. Morphologic characteristics of benign and malignant adrenocortical tumors. Cancer 198555 766-773.

10 Cryns VL, Thorr A, Xu HJ, Hu SX, Wierman ME \& Vickery AL et al. Loss of the retinoblastoma tumor-suppressor gene in parathyroid carcinoma. New England Journal of Medicine 1994 $330757-761$.

11 Dotzenrath C, Teh BT, Farnebo F, Cupisti K, Svensson A \& Toell A et al. Allelic loss of the retinoblastoma tumor suppressor gene: a marker for aggressive parathyroid tumors? Journal of Clinical Endocrinology and Metabolism 199681 3194-3196.

12 Farnebo F, Auer G, Farnebo LO, Teh BT, Twigg S \& Aspenblad U et al. Evaluation of retinoblastoma and Ki-67 immunostaining as diagnostic markers of benign and malignant parathyroid disease. World Journal of Surgery 199923 68-74.

13 Gicquel C, Raffin-Sanson ML, Gaston V, Bertagna X, Plouin PF, Schlumberger $\mathrm{M}$ et al. Structural and functional abnormalities at 11 p15 are associated with the malignant phenotype in sporadic adrenocortical tumors: study on a series of 82 tumors. Journal of Clinical Endocrinology and Metabolism 199782 2559-2565.

14 Weber MM, Auernhammer CJ, Kiess W \& Engelhardt D. Insulinlike growth factor receptors in normal and tumorous adult human adrenocortical glands. European Journal of Endocrinology $1997136296-303$. 
15 Boulle N, Logie A, Gicquel C, Perin L \& Le Bouc Y. Increased levels of insulin-like growth factor II (IGF-II) and IGF-binding protein-2 are associated with malignancy in sporadic adrenocortical tumors. Journal of Clinical Endocrinology and Metabolism 1998 83 1713-1720.

16 Marx C, Wolkersdörfer GW, Brown JW, Scherbaum WA \& Borstein SR. MHC class II expression - a new tool to assess dignity in adrenocortical tumors. Journal of Clinical Endocrinology and Metabolism $1996 \mathbf{8 1} 4488-4491$.

17 Suzuki T, Sasano H, Nisikawa T, Rahme J, Wilkinson DS \& Nagura H. Discerning malignancy in human adrenocortical neoplasms: utility of DNA flow cytometry and immunohistochemistry. Modern Pathology 19925 224-231.

18 Cote RJ, Cordon-Cardo C, Reuter VE \& Rosen PP. Immunopathology of adrenal and renal cortical tumors. Coordinated change in antigen expression is associated with neoplastic conversion in the adrenal cortex. American Journal of Pathology 19901361077 1084.

19 Goldblum JR, Randall S, Kaldjian EP, Thiny M, Davenport R, Thompson N \& Lloyd RV. Immunohistochemical assessment of proliferative activity in adrenocortical neoplasms. Modern Pathology 19936 663-668.

20 Reincke M, Wachenfeld C, Mora P, Thumser A, Jaursch-Hancke C, Abdelhamid $S$ et al. p53 mutations in adrenal tumors: caucasian patients do not show the exon 4 Hot Spot found in Taiwan. Journal of Clinical Endocrinology and Metabolism 199681 36363638 .

21 Ohgaki H, Kleihues P \& Heitz PU. p53 mutations in sporadic adrenocortical tumors. International Journal of Cancer $1993 \mathbf{5 4}$ 408-410.

22 Skogseid B, Larsson C, Lindgren PG, Kvanta E, Rastad J, Theodorsson E et al. Clinical and genetic features of adrenocortical lesions in multiple endocrine neoplasia type 1. Journal of Clinical Endocrinology and Metabolism 199275 76-81.

23 Skogseid B, Rastad J, Gobl A, Larsson C, Backlin K, Juhlin C et al. Adrenal lesion in multiple endocrine neoplasia type 1. Surgery 1995118 1077-1082.

24 North DN, Kovacs WI \& DeBold CR. The adrenal cortex. In Williams Textbook of Endocrinology, edn 8, pp 489-621. Eds ID Wilson \& DW Foster. Philadelphia: Saunders, 1992.

25 Nakamura Y, Leppert M, O'Connell P, Wolff R, Holm T \& Culver M et al. Variable number of tandem repeat (VNTR) markers for human gene mapping. Science 1987235 1616-1622.
26 Gavrieli Y, Sherman Y \& Ben-Sasson SA. Identification of programmed cell death in situ via specific labeling of nuclear DNA fragmentation. Journal of Cell Biology 1992119 493-511. 27 Larsson C, Calender A, Grimmond S, Giraud S, Hayward NK, Teh B et al. Molecular tools for presymptomatic testing in multiple endocrine neoplasia type 1. Journal of Internal Medicine 1995238 239-244.

28 Vargas MP, Vargas HI, Kleiner DE \& Merino MJ. The role of prognostic markers (MiB-1, RB, and bcl-2) in the diagnosis of parathyroid tumors. Modern Pathology 199710 12-17.

29 Mizoue T, Kawamoto H, Arita K, Kurisu K, Tominaga A \& Uozumi T. MIB1 immunopositivity is associated with rapid regrowth of pituitary adenomas. Acta neurochirurgica Wien 1997 139 426-431; discussion 431-432.

30 La-Rosa S, Sessa F, Capella C, Riva C, Leone BE \& Klersy C et al. Prognostic criteria in nonfunctioning pancreatic endocrine tumours. Virchows Archiv $1996429323-333$.

31 Basolo F, Pollina L, Fontanini G, Fiore L, Pacini F \& Baldanzi A. Apoptosis and proliferation in thyroid carcinoma: correlation with bcl-2 and p53 protein expression. British Journal of Cancer 199775 537-541.

32 Garzetti GG, Ciavattini A, Goteri G, De-Nictolis M, Stramazzotti D, Lucarini G et al. Ki67 antigen immunostaining (MIB 1 monoclonal antibody) in serous ovarian tumors: index of proliferative activity with prognostic significance. Gynecologic Oncology $1995 \mathbf{5 6} 169-174$.

33 Albers P, Orazi A, Ulbright TM, Miller GA, Haidar JH, Donohue JP et al. Prognostic significance of immunohistochemical proliferation markers (Ki-67/MIB-1 and proliferation associated nuclear antigen), p53 accumulation, and neovascularization in clinical stage A nonseminomatous testicular germ cell tumors. Modern Pathology 19958 492-497.

34 Barzon L, Scaroni C, Sonino N, Fallo F, Paoletta A \& Boscaro M. Risk factors and long-term follow-up of adrenal incidentalomas. Journal of Clinical Endocrinology and Metabolism 199984 520526.

Received 20 November 2000

Accepted 9 May 2001 